\title{
Effect of Aloe vera Extract in Reducing Formaldehyde in Salted Squid (Loligo indica) and Sensory Evaluation
}

\author{
Safrida Safrida ${ }^{1 *}$ Devi Syafrianti ${ }^{1}$, and Irma Haryani $^{1}$ \\ ${ }^{1}$ Department of Biology Education, Faculty of Teacher Training and Education, Universitas Syiah Kuala, Darussalam, Banda \\ Aceh, Indonesia.
}

\begin{abstract}
This study aims to determine the effect of Aloe vera extract in reducing formaldehyde levels in salted squid and determine the organoleptic characteristics of salted squid after being given Aloe vera extract. This study used a completely randomized design (CRD) with 4 treatments and 6 replications: P0 (0\% Aloe vera extract), P1 (10\% Aloe vera extract), P2 (20\% Aloe vera extract), and P3 (30\% Aloe vera extract). Data were analyzed by using an analysis of variants at a significant level $\alpha=0.05$ followed by Duncan's Test. The average formalin content before given aloe vera extract in P0, P1, P2, P3 was $3.65 \mathrm{mg} / \mathrm{L}, 4.08 \mathrm{mg} / \mathrm{L}, 4.09$ $\mathrm{mg} / \mathrm{L}, 3.96 \mathrm{mg} / \mathrm{L}$, respectively and after being given aloe vera extract was $2.75 \mathrm{mg} / \mathrm{L}, 2.58 \mathrm{mg} / \mathrm{L}, 1.63 \mathrm{mg}$ / L, $2.82 \mathrm{mg} / \mathrm{L}$, respectively. Administration of Aloe vera extract showed a significant reduction of formaldehyde levels in salted squid $(\mathrm{p}<0.05)$. Moreover, it was affecting the quality of salted squid in terms of color, aroma, and texture. It can be concluded that the administration of $20 \%$ Aloe vera extracts effective for reducing the formaldehyde levels, improve the quality of color, aroma, and texture in salted squid.
\end{abstract}

Keywords: aloe vera, salted squid (Loligo indica), formaldehyde.

\section{Introduction}

Squid are invertebrate animals, from the Mollusca phylum and the Cephalopoda class [1]. Squid is much loved by the people because of its delicious taste and texture. Squid is one of the most easily decomposed fisheries commodities. This is a major problem that arises among producers. To prevent these losses, many producers use dangerous preservatives such as formalin in food products. Preservatives are one of the additional ingredients that are inserted into food so that the food is more durable and does not rot quickly. The purpose of using preservatives is to reduce or prevent the growth of microorganisms such as bacteria, toadstool, and yeast [2]. According to Suryadi [3], states that formaldehyde contamination in food ingredients is very dangerous to the body. According to Bardana and Montanaro [4]. Formalin is classified as a hazardous chemical because it is very easy to produce toxic formaldehyde gas. Formalin can react quickly with the mucous layer of the digestive tract and the respiratory tract [5]. One of the efforts made to reduce formaldehyde levels is by using extracts from several plants. The plants that are believed to be able to reduce formaldehyde levels in preserved fishery products are Aloe vera plants. This plant has been known and used for thousands of years because of its extraordinary properties and benefits [6]. According to Fadhilah [7] Aloe vera plants have active compounds that can be used to minimize the presence of formalin in milkfish fillets, saponins so that residual levels of formalin can be reduced after being soaked in aloe vera solution". Research on the use of natural ingredients, one of which is aloe vera in an effort to reduce the levels of formalin contained in salted squid has never been done. Then a study to prove that aloe vera extract can reduce formalin in salted squid. This study aims to determine the effect of aloe vera extract in reducing formaldehyde levels in salted squid

\section{Materials and Methods}

This research was conducted in August - January 2015 at the Unsyiah Chemical Education Study Program Laboratory for the manufacture of aloe vera extract and the Regional Technical Implementation Unit (UPTD) of the Banda Aceh City Laboratory as a place for testing the formaldehyde content.

The tools and materials used are analytical scales, mortar pounders, chemical beakers, beaker glass, spectrophotometers, test tubes, measuring pipettes, measuring cups, digital cameras, and plastic plates. The ingredients used are aloe vera, salted squid, ethanol $70 \%$ aquadest, $\mathrm{HCHO}-1$ reagent, and $\mathrm{HCHO}-2$ reagent.

Making aloe vera extract using a maceration method that uses $2 \mathrm{~kg}$ of aloe vera with 5 liters of ethanol. Aloe vera is washed clean, cleaned from its skin, finely cut, then air-dried for 24 hours. Then soak it using 10 liters of $70 \%$ ethanol for 24 hours. The filtering results are then evaporated using a rotary evaporator at a temperature of 65 degrees Celsius to remove the ethanol content in aloe vera so that a $100 \%$ concentrated extract was obtained [8]. The concentrations used were $0 \%(\mathrm{P} 0), 10 \%(\mathrm{P} 1)$,

Corresponding author: saf_rida@unsyiah.ac.id 
$20 \%$ (P2) and 30\% (P3) with 60 minutes soaking time [9]. Giving aloe vera extract in salted squid was done by soaking in accordance with the treatment for 60 minutes. Formalin levels were measured before and after the administration of aloe vera extract using the HCHO-1 reagent and $\mathrm{HCHO}-2$ reagent methods. After observing, the squid was cooked by boiling and then sensory tests were performed with a hedonic test using a score of $5=$ very like, $4=$ like, $3=$ neutral, $2=$ dislike, $1=$ very dislike. Hedonic tests are carried out by a team of expert panelists and trained panelists.

The data obtained were analyzed by Variant Analysis (ANOVA) using a Completely Randomized Design (CRD) and continued with the Duncan test.

\section{Results and Discussion}

The results of studies that have been carried out on the average levels of formaldehyde in salted squid before and after given aloe vera extract in each treatment can be seen in figure 1. Descriptively, the percentage decrease in formaldehyde levels after being given aloe vera extract soaked for 60 minutes has decreased when compared with formaldehyde levels before being given aloe vera extract can be seen in Figure 1.

Figure 1 shows that there are differences in the average initial levels of formalin in salted squid before being treated with aloe vera extract and the average levels of formalin in salted squid after being treated with aloe extract. On the average initial levels of formalin salted squid before being given treatment did not get significantly different results because Fcount $\leq \mathrm{F}$ table so that the initial data were homogeneous. Whereas in the treatment after aloe extract was given significantly different results, because of Fcount $\geq$ Ftable. In the control treatment (P0) with a concentration of $0 \%$ seen a decrease in formalin levels of salted squid after being soaked with aqudest by $24 \%$, in the treatment (P1) with the addition of aloe vera extract at a concentration of $10 \%$ there was a decrease in formalin levels by $36 \%$, then in the treatment (P2) with a concentration of $20 \%$ after the addition of aloe vera extracts there was a decrease in formalin content by $60 \%$, and in the treatment $(\mathrm{P} 3)$ with a concentration of $30 \%$ after the addition of aloe vera extract the levels of formalin decreased by $28 \%$. From the results of research conducted that the results of the analysis of the 4 formaldehyde content found the highest levels of formaldehyde reduction in the administration of aloe vera extract $20 \%$ (P2 treatment). The results of the testing of aloe vera extract on decreasing the levels of formalin in salted squid were further analyzed using the ANOVA test.



Figure 1. Average level of squid formalin before and after the treatment of aloe extract

Based on the ANAVA test it was found that Fcount $\geq$ Ftable which means that the administration of aloe vera extract with various concentrations had a significant effect on the decrease in formaldehyde levels in salted squid. ANOVA results continued with Duncan's test can be seen in Table 1.

Table 1. Duncan Test Decrease in Formalin Levels in Salted Squid After Given Aloe Vera Extract

\begin{tabular}{lccccc}
\hline \multirow{2}{*}{ Treatment } & \multicolumn{4}{c}{ Treatment } & \multirow{2}{*}{ Average } \\
\cline { 2 - 4 } P2 $(1,63)$ & $\mathrm{P} 2(1,63)$ & $\mathrm{P} 1(2,58)$ & $\mathrm{P} 0(2,75)$ & $\mathrm{P} 3(2,82)$ & $1,63 \mathrm{a}$ \\
$\mathrm{nyyyn}$ P1 $(2,58)$ & - & $0,95^{*}$ & $1,12^{*}$ & $1,19^{*}$ & $2,58 \mathrm{~b}$ \\
$\mathrm{P} 0(2,75)$ & $0.95^{*}$ & - & $0,17^{\mathrm{ns}}$ & $0,24^{\mathrm{ns}}$ & $2,75 \mathrm{bc}$ \\
$\mathrm{P} 3(2,82)$ & $1,12^{*}$ & $0,17^{\mathrm{ns}}$ & - & $0,07^{\mathrm{ns}}$ & $2,82 \mathrm{bc}$ \\
\hline
\end{tabular}

Note: $*=$ Significantly different at the $5 \%$ level. $\mathrm{ns}=$ Not significantly different

Table 2. Organoleptic Test Results for Color, Aroma, Taste, and Texture in salted squid after administration Aloe vera (Average value and standard deviation (SD)

\begin{tabular}{|c|c|c|c|c|}
\hline Treatment & Color & Flavor & Taste & Texture \\
\hline P0 (0\% Aloe vera extract) & $4,0 \pm 1,55^{\mathrm{d}}$ & $4,4 \pm 0,59^{c}$ & $4,0 \pm 0.61^{\mathrm{d}}$ & $3,85 \pm 0.67^{c}$ \\
\hline P1 (10\% Aloe vera extract) & $4,3 \pm 0,57^{c}$ & $4,45 \pm 0,51^{\mathrm{b}}$ & $4,15 \pm 0.67^{b}$ & $3,75 \pm 0.71^{\mathrm{d}}$ \\
\hline P2 (20\% Aloe vera extract) & $4,5 \pm 0,51^{\mathrm{a}}$ & $4,55 \pm 0,51^{\mathrm{a}}$ & $4,55 \pm 0.51^{\mathrm{a}}$ & $4,05 \pm 0.68^{\mathrm{a}}$ \\
\hline P3 (30\% Aloe vera extract) & $4,25 \pm 0,71^{\mathrm{b}}$ & $4,2 \pm 0,69^{d}$ & $4,1 \pm 0.71^{\mathrm{c}}$ & $3,9 \pm 0.64^{\mathrm{b}}$ \\
\hline
\end{tabular}

Note: 5 = very like, 4 = like, $3=$ neutral, $2=$ dislike, $1=$ very dislike. Data are presented as mean \pm SD. $(n=20)$. Different letter notations on the same line show that they are significantly different $(p>0.05)$. 
Table 2 showed that the results of the sensory evaluation test showed that the administration of extracts of $20 \%$ (P2) had a higher preference for color, aroma, taste, texture compared to controls and other treatments. In Table 2, it can be seen that there is a significantly different effect between treatments or in other words the amount of decrease in formaldehyde levels in salted squid after being given aloe vera extract decreases. There is a significantly different effect on each different treatment. Then P2 treatment is significantly different from all treatments with the notation "a", therefore P2 is the best treatment with an optimal dose of $20 \%$ effective in reducing formaldehyde levels.

Based on the results of research that has been done, it is known that the administration of aloe vera extract is effectively used to reduce formaldehyde levels in salted squid. In the treatment P0 (control) it can be seen that the levels of formalin can also be reduced even if only soaked with aquadest or without extract treatment with a decrease in the amount of $0.91 \mathrm{mg} / \mathrm{L}$. Decrease in formaldehyde levels in the control treatment is due to the nature of formaldehyde which is soluble in water. The process of withdrawal of formalin by water occurs due to the osmosis event which is the process of transferring solvents (water) from a solution that has a low concentration through a semipermeable membrane (squid) to a solution that has a higher concentration (formalin) until a concentration equilibrium is reached. So the levels of formaldehyde in salted squid can be reduced due to the entry of water in salted squid.

Decrease in formaldehyde levels in salted squid after administration of aloe vera extract at a concentration of $10 \%$ (P1) is the lowest optimum point that can reduce formaldehyde levels, but less effective at $1.51 \mathrm{mg} / \mathrm{L}$. The P2 treatment with a concentration of $20 \%$ aloe vera extract was more effective in reducing formaldehyde levels among other treatments with a decrease amount of $2.46 \mathrm{mg} / \mathrm{L}$. Based on research results obtained the best concentration in soaking aloe vera extract solution for 60 minutes was found at a concentration of $20 \%$ (P2). In accordance with the study of Fadhillah [7] which uses aloe vera to reduce formaldehyde levels in milkfish fillets, it is explained that the residual levels of formalin in milkfish fillets have decreased in line with the higher concentration of aloe vera where aloe vera contains saponins. Saponins can bind formalin so that formaldehyde content in milkfish fillets can be reduced. Formalin levels in milkfish fillets can decrease due to the presence of saponin compounds that can bind formalin particles and dissolve with water.

This can be attributed to the way it works like surfactants. The existence of the two groups on surfactants (polar and non-polar) in saponin compounds has the qualifications to form water and formalin emulsions so that saponins act as emulsifiers. Emulgator is a surface-active agent (surface active agent) that can produce foam stability due to a decrease in surface tension in the liquid so that it has a good cleaning power compared to water alone. The surfactant adsorbs into the inter-phase region and binds formaldehyde particles to obtain the stability of the emulsion from the polar group. The ability of surfactants to improve emulsion stability depends on the contribution of the polar (hydrophilic) and non-polar (hydrophobic) groups. After formalin is bound by the saponin compound, the saponin will dissolve and form micelles. The results show that the addition of aloe vera can reduce formalin levels higher than without the addition of aloe vera.

P3 treatment with a concentration of $30 \%$ decreased levels of formalin also reduced by $1.14 \mathrm{mg} /$ $\mathrm{L}$, but from the average results obtained decreased levels of formalin were less than the administration of concentrations of $10 \%(\mathrm{P} 1)$ and $20 \%(\mathrm{P} 2)$. This is because the higher concentration of aloe vera extract does not affect reducing the levels of formalin contained in salted squid, according to the results of the study (Figure 4.2) which explains that the decrease in formalin levels in salted squid with higher concentrations does not affect the decrease in formaldehyde levels in salted squid. Therefore the best concentration in soaking aloe vera extract solution for 60 minutes was found at a concentration of $20 \%$ (P2).

\section{Conclusion}

The conclusions obtained in this study are the administration of aloe vera extract by as much as $20 \%$ can effectively reduce the levels of formalin in salted squid.

\section{References}

1. Campbell NA: Biologi. Jakarta. Erlangga 5. 2003.

2. Udjiana S: Upaya Pengawetan Makanan Menggunakan Ekstrak Lengkuas. Jurnal Teknologi Separasi. 2008; 1(2).

3. Suryadi H: Analisis Formalin Dalam Sampel Ikan Dan Udang Segar Dari Pasar Muara Angke. Majalah Ilmu Kefarmasian. 2010; 7(3).

4. Bardana EJ, Montanaro: A Formaldehyde an Analysis of its Respiratory, Cutaneneous, and Immunologic Effects Ann. Alergy. 1991 ; 66(8).

5. Ali M, Suparmono, Hudaidah S: Evaluasi Kandungan Formalin pada Ikan Asin Di Lampung. Jurnal Ilmu Perikanan dan Sumberdaya Perairan. 2014; 11(2).

6. Handayani T: Apotek Hidup. Jakarta. Padi. 2013.

7. Fadhilah A, Ma'ruf WF, Rianingsih L: Efektivitas Lidah Buaya (Aloe vera) di Dalam Mereduksi Formalin Pada Fillet Ikan Bandeng (chanos chanos Forsk) Selama Penyimpanan Suhu Dingin. Jurnal Pengolahan dan Bioteknologi Hasil Perikanan. 2013; 2(3).

8. Ma'mun: Teknik Pembuatan Simplisa dan Ekstrak Purwoceng. Laporan Pelaksanaan Penelitian Tanaman Obat dan Aromatik. 2006; 314-324.

9. Damayanti E, Ma'ruf WF, Wijayanti I: Efektivitas Kunyit (Curcuma Longa Linn.) Sebagai Pereduksi Formalin Pada Udang Putih (Penaeus Merguiensis) Penyimpanan Suhu Dingin. Jurnal Pengolahan dan Bioteknologi Hasil Perikanan. 2014; 3(1). 